Article

\title{
Environmental Diversity Assessment to Enhance Attractineness of Eco-tourism in Asir Region, Saudi Arabia
}

\author{
Jamilah Al Mohaya and Mena Elassal * \\ Department of Geography, Faculty of Humanities, King Khalid University. \\ * Correspondence: menaelassal_83@yahoo.com
}

\begin{abstract}
This is study follows environmental diversity assessment for geotourism development in Asir region. Geotourism seeks to supporting the tourism landscape in its interaction with the historical and archaeological, architectural or immaterial heritage, and requires diversification in terms of product, market and geographical potential. The study is based on various tourist facades and environmental diversity in Asir. As tourism development is a comprehensive undertaking involving many sectors, and these are the challenges to which the country's tourism industry should respond to promote domestic tourism. quality and spatial pattern of tourism resources, climate comfort, and natural disaster possibility. Based on analyze multi-source datasets collected, geomorphological features of this area, we created a GIS database comprising geologic and topographic maps, and satellite images using these datasets. The findings of the study provided valuable insights into the role of environmental diversity in achieving tourism. The study examined the interrelationship between tourism and environmental diversity.
\end{abstract}

Keywords: environmental diversity; eco-tourism; Asir region; GIS; RS

\section{Introduction:}

The concept of geotourism the terms of geological and geomorphological and the importance of preserving them for their use in tourist purpose: "the provision of interpretative facilities and services to promote the value and social benefit of geologic and geomorphologic sites and their materials and to ensure their conservation, for the use of tourists"(Gavrlla, et al, 2011, p.198). For the geomorphological heritage concept were also used different terms like: geomorphological assets, geomorphological goods, geomorphological sites, geomorphological geotopes, and sites of geomorphological interest. In the present, for the geomorphological heritage concept is used the term of "geomorphosite" (Reynard, 2005).

The term was defined as being a landform that has acquired a special value due to human perception. Thus, the geomorphosites, due to the human perception has two main values: scientific value and additional values (Reynard, 2005). So, geomorphosites are considered natural goods not only because of their intrinsic value (scientific, aesthetic), but also due to their extrinsic values (ecologic, historical, cultural, economic) thus forming the main resources underlying the development of geotourism. The concept of nature conservation was advocated as an environmental necessity. This was spurred by increased environmental awareness in terms of the effects of extinction. The cessation of a natural process is not reversible. Organisms that go extinct remain so forever. As much as it is our duty to conserve archaeological sites and rare artistic creations, we are responsible for maintaining environmental diversity at all including levels genetic diversity, species diversity and the diversity of the ecological systems. Besides, nature conservation is in the best interest of humanity considering that the environment is the provider of products and services, which sustain human life (Mooney, Postel, Schneider, Tilman \& Woodwell, 1997). 
This study approaches a topical issue and follow the assessment of the Asir region to enhance attractineness of eco-tourism in the study area. In order to achieve the proposed objectives were made field observation and were used the methods of geological and geomorphological mapping, photo-interpretation and digital mapping. As a result, we identify the most representative elements of the topography and we realized a digital map of landforms with geotouristic potential. Due to the strategic location of Asir, which gives the region a high level of biodiversity, residents of the province enjoy relatively good atmosphere throughout the year. The high plains of Asir support the growth of many high-altitude trees, such as juniper and AL-Taleh. Medium elevation ranges (800$1,500 \mathrm{~m}$ ) support coffee trees, as well as AL-Salam, AL-Sidr and olive trees. On the other hand, ALDome and al-Arak trees grow in abundance in the coastal plains of the province. According to ALWadee (2010), Saudi Arabia has more than 2243 wild plant species. Approximately $70 \%$ of the floras of Asir have medical uses and include many aromatic plants, which can generate revenues and contribute to the economy of use. However, these species are concentrated in different parts of the province, especially in the forests of AL-Fraa, Suda and AL-Serma, which cover an estimated area of about 457,780 hectares. It goes without saying that biodiversity is on the vanguard of cultural diversity, economic growth and environmental sustainability. It generates non-direct benefits and contributes to a larger gene pool (Eshtayeh \& Jamus, 2002, p.28).

\section{Review of literature:}

Ecotourism has been defined differently by different experts and several concepts are presented. The definition provided by World Tourism Organization includes any type of travel that includes at least one night, but no more than one year, away from usual place of residence (Swarbrook, 1999).

Ecotourism is a combination of eco and tourism or ecological tourism. Though there is no exact definition for ecotourism, the following definition can be provided: it "is a form of tourism inspired primarily by the natural history of an area, including its indigenous cultures" (Ziffer, 1989, p. 6). Ziffer also points to a number of characteristics of ecotourism which include visiting undeveloped areas in the spirit of appreciation, participation, and sensitivity, practicing a non-consumptive use of wildlife and natural resources and contributing to the visited area through labor or financial means.

Recently there has been a surge of interest in studying ecotourism and the attempts that have been made gained noticeable results. Such as Ólafsdóttir and Dowling (2013): in their investigative attempt emphasized the importance of sustainable management in geotourism development. The authors aimed to assess the compatibility of geoconservation and rural development within geotourism by exploring the challenges and potential outcomes of the geotourism development in Iceland; by identifying and analyzing the various potential outcomes of geopark development; and by proposing a strategic planning approach for sustainable geotourism planning and management in vulnerable environments. The results of their study pointed to nine distinctive sites for geopark development, each of which presented the major challenge of using geological heritage as a basis for informing the area's ' $A B C$ ' components such that both visitors and locals are given a holistic appreciation of the area based on an understanding of its geology.

Chiu, Lee and Chen (2014): studied the environmentally responsible behavior of tourists engaged in ecotourism and they investigated whether its level can change as a result of the ecotravel experience. In their article, Chiu et al. proposed a behavioral model in which perceived value, satisfaction and activity involvement with respect to the eco-travel experience shape the tourist's environmentally responsible behavior. The results of analyzing 328 questionnaires showed that perceived value, satisfaction, and activity involvement could promote environmentally responsible behavior of tourists. The authors concluded that enhancing tourist's value perception about the ecotravel activity was a priority in a sequence of steps that would strengthen environmentally responsible behavior via increasing the ecotourism's activity involvement and satisfaction levels. 
Tran and Walter (2014) in a quite recent research about ecotourism, gender and development in northern Vietnam investigated women's participation in a community-based ecotourism project. Applying Longwe's empowerment framework, the authors found a more equitable division of labor, increased income, self-confidence and community involvement, and new leadership roles for women. Nevertheless, they found inequities of social class, childcare, and violence against women.

Ahmad (2014) in another study in Brunei Darussalam in Southeast Asia attempted to identify the prospect as well as challenges of sustainable tourism from the perspective of the business organizations or enterprises in the tourism industry, based on data that were collected from a survey conducted among travel, transport, hospitality and visitor attraction sectors in the country.

\section{Study area:}

Asir is a model for the Kingdom's geographical regions differentiated in its topography and environmentally diverse. The Asir region is located in the southwestern part of Saudi Arabia within the Arabian Shield region, this is the region most regions of the Kingdom heightest and most rugged. It has an area of $84,365 \mathrm{~km}^{2}$ (Map 1). It shares a short border with Yemen. Its capital is Abha, and other towns include Khamis Mushayt, Bishah and etc. Geographically, the Asir region is situated on a high plateau that receives more rainfall than the rest of the country and contains the country's highest peaks, which rise to almost 3,015 meters at Mount Sawdah near Abha. Such variations make Asir a region of more natural vegetation than any other part of Saudi Arabia. Some sheltered areas even have dense coniferous forests and fruit trees, albeit the exposed ridges still being very dry. It brought with him a variation in temperature and climate to provide winter and summer tourism.

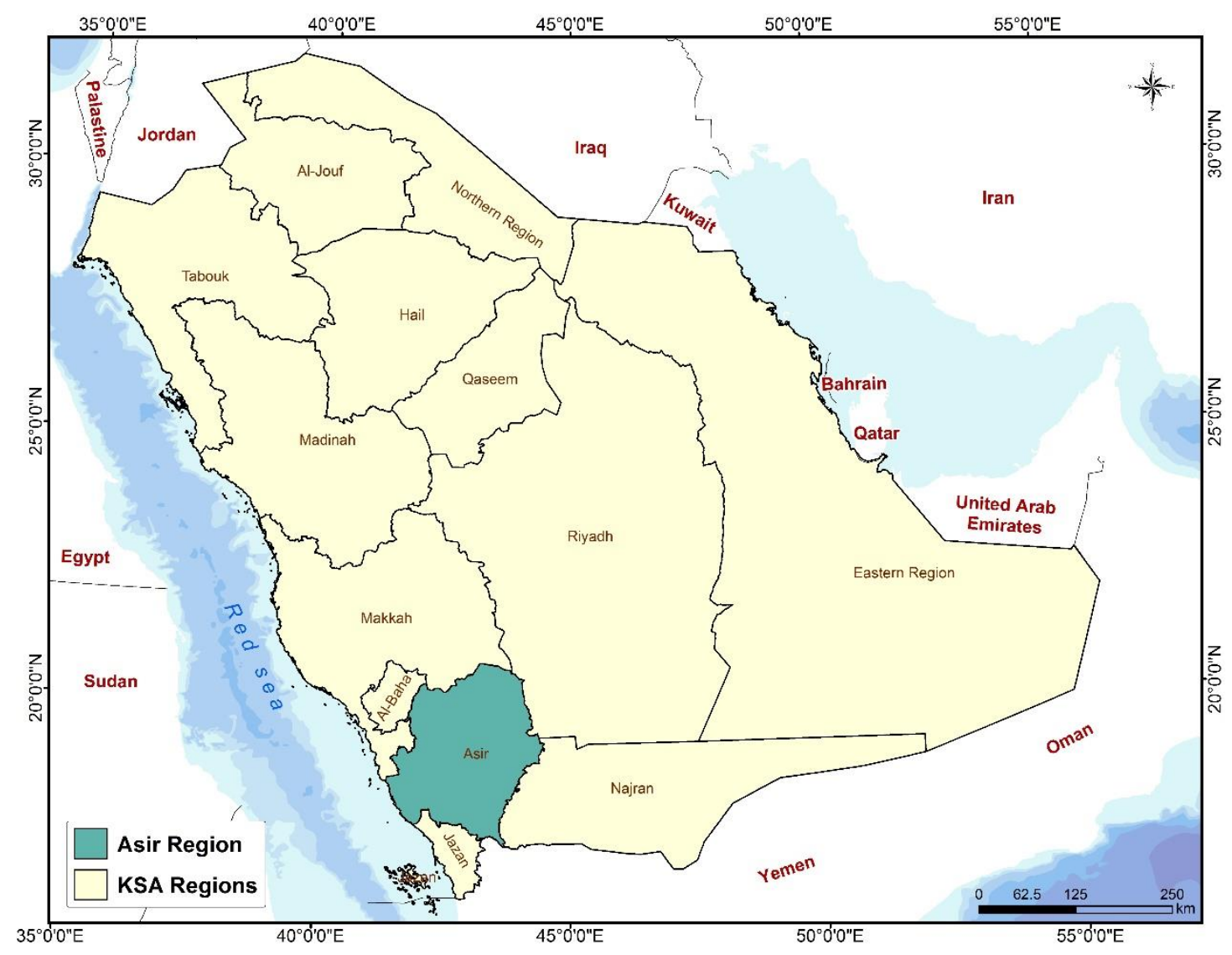

Source: KSA Administrative Data, Updated Guidebook of the population names manual in the preparatory stages for the agricultural census $1436 \mathrm{AH}$.

Figure 1. Location of the study area. 
The average annual rainfall in the highlands probably ranges from 300 to 500 millimeters (12 to 20 inches) falling in two rainy seasons, the chief one being in March and April with some rain in the summer. Temperatures are very extreme, with diurnal temperature ranges in the highlands the greatest in the world. It is common for afternoon temperatures are over $30^{\circ} \mathrm{C}\left(85{ }^{\circ} \mathrm{F}\right)$, while mornings can be extremely frosty, and fog can cut visibility to near zero percent. As a result, there is much more natural vegetation in Asir than in any other part of Saudi Arabia, with sheltered areas even containing areas of dense coniferous forests, though more exposed ridges still are very dry. Asir is home to many farmers who chiefly grow wheat and fruit crops, though irrigation has greatly expanded production in modern times (Som \& Al-Kassem, 2013, p.2).

As mentioned above, the climate of Asir is semi-arid as it is influenced by its high elevation. In stark contrast to a large portion of Saudi Arabia, the climate in this region is both cooler and wetter. Hence, the Saudi government has been promoting Asir as a tourist destination and has created events, such as the 'Abha Festival' during the summer each year, to draw people to the city and its surrounding attractions. Abha International Airport, that lies to the east of the city, receives direct flights from major cities in the country as well as international flights from cities in the Gulf region (Som and Al-Kassem, 2013, p. 3). This area, three thousand meters above the sea level, is distinguished with their moderate weather in summer and beautiful scenery. Asir region is distinct not only for its natural scenery, forests and wild trees which cover most of the area, but also is well known for its heritage attraction and beaches at the foot of the mountain.

\section{Methodology:}

The analysis of environmental diversity assessment to enhance attractineness of ecotourism in Asir region was realized in two stages: the first stage consisted of field campaigns in which morphological information were accumulated and the second stage consisted in achieving the map of landforms with geotouristic potential from our study area.

In the following stage (laboratory stage), by GIS analysis, we realized the digital elevation model of the Asir region. On digital elevation model were added the morphological information obtained during the field campaigns like ridges, peaks, steep slopes, gorges and quarries. Downscaled data will be further used for evaluation of natural conditions. DEM and NDVI are used as variables for air temperature downscaling. Land surface temperature and average precipitation are considered as independent variables for relative humidity and wind speed. Before downscaling, an additional process.

Thus, by layers overlapping resulted a map that contains both the topography and morphology of Asir region. On the resulted map of our study area were represented only those landforms that can be easily identified in the field and which can be valorized from the touristic viewpoint, It is influenced by many factors, such as air temperature, relative humidity, surface wind speed, and solar radiation etc., and there exists complex relationships among different factors. Thus, thermal environment model and cold environment model are used for comprehensive evaluation of natural conditions in the following sections. Meanwhile, natural disaster risk is another important factor and it might relate to altitude, slope, precipitation, etc. On the map were also represented settlements, main access roads, adjacent morphological units etc. The resulted map which highlights the areas with geotouristic potential represents the first step in achieving the geotouristic map of the Asir region.

\section{Rectifiers tourist attractions in Asir:}

Asir contains natural and human resources, through which tourism can be developed and promoted on a planning basis, in the study area:

\section{The natural potential of the study area:}

Asir region has a natural potential Stunning, and diverse, it is found in most of its cities where it is characterized by its majestic mountains covered with various trees and flowers, as well as the 
valleys, springs and vast desert, there is no doubt that this environment varies considerably It can be exploited, in various promotional and tourism activities. Environmental and natural gifts lead to diversity for geo-tourism, and thus the development of tourism in Asir region.

\subsection{Geological Features}

The geological structure of the Asir Mountains is characterized by great diversity (both in terms of age and genesis) being resulted during Quaternary, Jurassic, Laterite, permian, Precambrian). It consists of various rock formations, In terms of geological age and structure rock. and deposited these rock formations from top to bottom, the study area is part of the Arabian Shield, which consists of a series of ancient volcanic rocks, dating back to 800-1000 million years. Which are composed of the sedimentary, volcanic, and metamorphic rocks formed during the protozoic periods. These rocks have been exposed since their formation and their origin to the movement of many distortion and transformation, which caused the disappearance of most of their original properties and cut with many massive to layered plutons, sills, dikes and irregular bodies. And different directions and shapes, most of these rocks originated in an environment Islands, it consists of the Pretorozoic Formation (walliam, 1985).

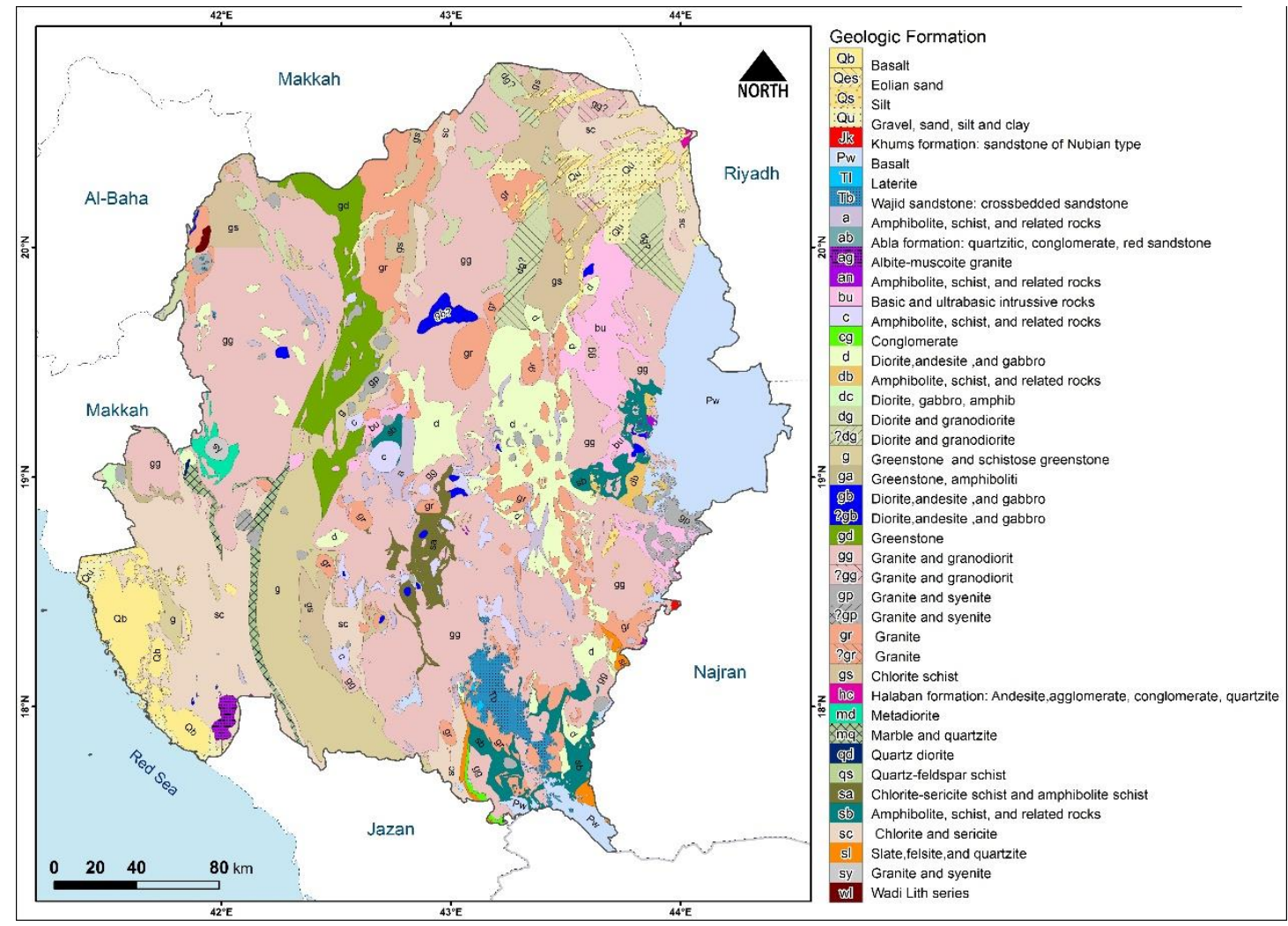

Source: Ministry of Petroleum and Mineral Resources - General Directorate of Mineral Resources (Asir JM 217), (Najd Southern JM 2011), (Southern Hijaz JM 210), (Tihama Sham JM 216), 500000 scale.

Figure 2. Geological formation map of study area.

\subsection{Topographical}

Sarat Mountains region: These mountains are high and extending to Yemen southward, steeply stoop towards Tihama, and be more like a wall. While slopes gradually towards Rub Al khali, the heads of valleys that descend towards Tihama are called "obstacles" from there, the population of Asir climb up and down to the Tihama. There is also in Asir Jebel Souda, which is 3015 meters above sea level, it is one of the highest mountain peaks in Saudi Arabia. It is 
characterized to the mountainous highlands by severe degradation to the west, where abound rocky cliffs, as for east, they descend steeper gradually to be the plateau and mountain slopes cut by the valleys.

Eastern Plateau: It extends to the east and north of the Asir mountain range, it is a flat plain between 600 and 1000 meters, its surface penetrates through inert volcanic peaks and rocky prophecies and consists of crumbed rocks eroded from the mountains.

Tihama Asir: Tihama Asir is located in the west of the study area, the area between the Sarat Mountains and the Red Sea coast, it extends from the western slopes of the Sarawat mountain range at a distance of 150-170 $\mathrm{km}$ approximately.

Plateau: This plateau extends from Alnoasf and Bakom north to the plateau of Najran and Sarwat Mountains in the south, from the Najd plateau in the east to the west Sarwat Mountains, and it is generally sloping towards the north and east, the height ranges between 600 to 1200 meters above sea level.

Coastal plain: It stretches from the western slopes of the Sarat mountain range, the distance does not exceed $150 \mathrm{~km}$. As well as where there is the coastal plain, which is a narrow Coastal bar, its width ranges between ten kilometers to thirty kilometers, the coastal plain rises about sea level at a rate ranging from 100 meters to 150 meters. It is punctuated by a number of canyons and valleys that carry rainfall water, on Sarat mountain range and pour in the direction of the Red Sea Figure (5).
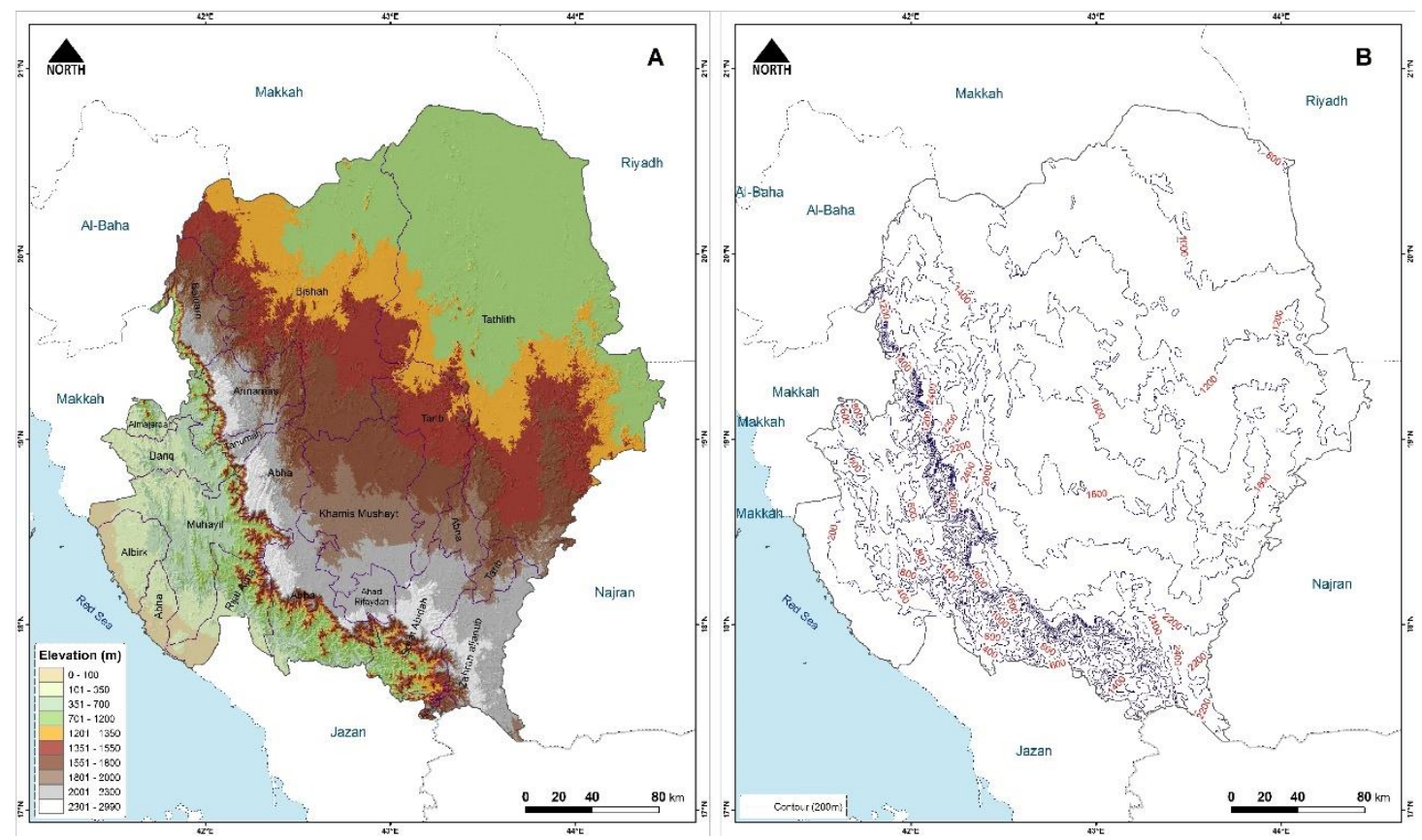

Source: shuttle Radar Topography Mission (SRTM) 3 Arc-Second Global, NASA \& NGA, 2011.

Figure 5. (A) Digital elevation model (DEM), and (B) Contour map of study area.

\subsection{Geomorphological}

The study area was divided into three major morphological ranges, and each range, it has properties characteristic geomorphology, they are the mountain, the plateau and the coastal plain ranges, In addition to Morpho Structural forms such as faults, dikes and rocky barriers (Main secondary). Figure (5) shows the most important main phenomena in the study area:

\section{Mountain range:}

This range is formed in the form of mountain ranges not connected, it is about a group of mountain blocks, extended straight nearly, separates this mountain mass from each other valleys 
accidental and longitudinal, Cracks played a major role in its extension and direction. This range includes the following geomorphological phenomena: Faults scarp, Hogbacks- Razorback scarps, Potholes, and Gorges.

The mountain range extends from north to south, adjacent to the Red Sea, known as the Asir Mountains. The mountains descend rapidly and suddenly towards the west to Red Sea coast and descend gradually towards the east. The mountains range a height of from 1500 meters to more than 3,000 meters. This elevation exceeds some of the high mountain peaks, such as the "Souda" mountain, 3015 meters above sea level. The highlands of the mountain range are water-dividing areas for valleys draining into direction east and west (Al- hidab, 1992, pp. 10-11).

\section{Plateau range:}

This range is the northern and eastern parts of the study area. This range represents the transition zone between the mountain range, known as the Piedmont range or the range of the mountain feet. This range is the sedimentation surface of the valleys and the spherical fans consisting of gravel, glamide, rock masses and sand. The surface of the scale is characterized by the relative flat and gradient of the gradient from west to east. It is characterized by a strong separation due to tectonic movements. Floodplains, Alluvial fans, Rocky hills, Rock outcrops, volcanic cones, Sediment valleys, Cuesta, Sand dunes and Isenberg.

\section{Coastal plain range:}

It is known as a Tihama Asir, narrow coastal plain. It is a specific geomorphological unit which consists some of basaltic flows and cones of volcanic ash materials, and the tongues of the aharat (Habib, 2005, p.9). On the Tihama Plain spans range of Parallel valleys, which descending from the mountains of Sarwat Such as the valleys of (Bish, Jizan and Sabia) and other short and fast-flowing valleys. It contains dry and wet sabkha, some of the high hills, Sand dunes, Coastal sandy plain, sharms, platform Reef, Mangrove, Coastal lakes, and deposits of lime and salt (Al-Sharif, 1984, p.41). 


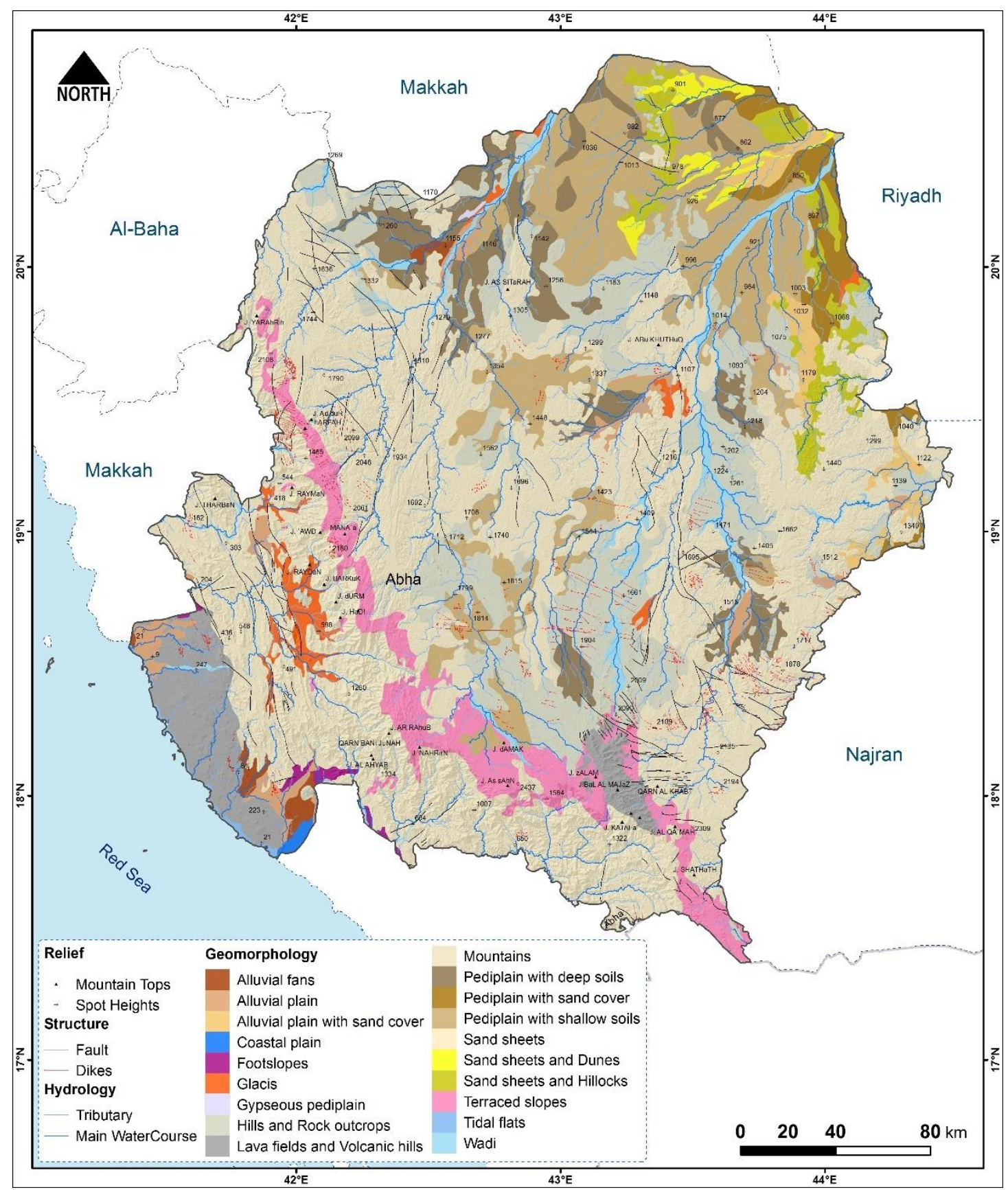

Source: Field Study, Geologic Map 500k, Topographic Maps 250k, SRTM Runoff Characteristics, Land resources Map (Land Resources Atlas, MEWA, 250k, 2011G).

Figure 3. Geomorphological Features map of study area.

\subsection{Climate}

Climate is a salient resource for tourism and a dominant attribute of a tourist destination. It has a major effect on tourism demand, satisfaction and decision-making, since tourists are sensitive to climate and climate change (Maddison, et all, 2001). Thus, it is vital to assess the suitability of climate for tourism for the sake of decision-making by tourism participants. For instance, tourism planners could better evaluate a destination for tourism development and incorporate climate in infrastructure planning and programming; the insurance industry might design diverse weather insurance products for the tourism industry; tourists can choose a destination and take out insurance on likelihood of poor weather conditions occurring while on holidays. Researchers have 
made considerable efforts to devise climate indices owing to the multifaceted nature of weather and the complex ways the weather variables come together to give meaning to climate for tourism. In this study, temperature-humidity index (THI) (Gonzalez, et all, 1974), are chosen to assess the thermal comfort and cold comfort, separately. Thermal comfort is the condition of mind that expresses human physiological satisfaction under the influence of temperature and humidity. THI is calculated by mean of dry bulb temperature and relative humidity and its expression is as followed (Gonzalez, et all, 1974)):

$$
T H I=t_{d}-0.55(1-0.01 R H)\left(t_{d}-14.5\right)
$$

where td represents the dry bulb temperature $\left({ }^{\circ} \mathrm{C}\right), \mathrm{RH}$ is relative humidity $(\%)$. Herein, monthly mean air temperature and relative humidity are used for calculation of THI and are reclassified into five categories: Cold, cool, comfortable, warm and hot, Table (1) according to Kyle's study of the bioclimatic environment.

Table 1. Classification of temperature-humidity index (THI) and wind effect index (WEI).

\begin{tabular}{ccc}
\hline THI $\left({ }^{\circ} \mathbf{C}\right)$ & Category & WEI \\
\hline$-1.7 \sim 13.0$ & Cold & $-800 \sim-600$ \\
\hline $13.0 \sim 14.0$ & Cool & $-600 \sim-300$ \\
\hline $15.0 \sim 20.0$ & Comfortable & $-300 \sim-200$ \\
\hline $20.0 \sim 26.5$ & Warm & $-200 \sim-50$ \\
\hline $26.5 \sim 29.9$ & Hot & $-50 \sim 80$ \\
\hline
\end{tabular}

Source: (Jiang et al, 2018, p. 3).

The characteristics of the climate in Asir can be described as "four distinctive seasons, comfortable spring, warm autumn, no severe cold in winter, and no intense heat in summer". It means that Asir is semi-arid as it is influenced by its high elevation, in stark contrast to a large portion of Saudi Arabia, the climate in this region is both cooler and wetter.

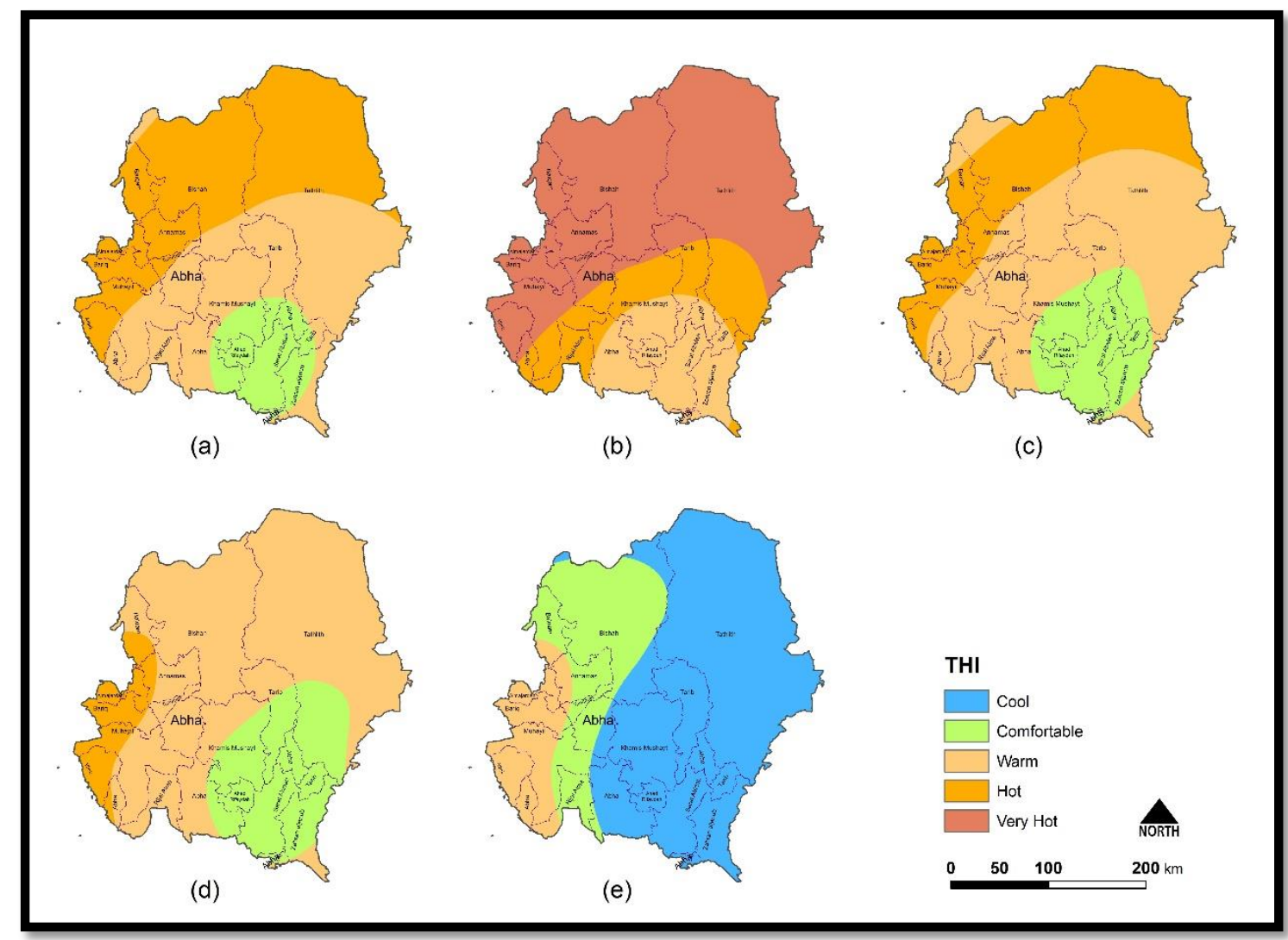


Source: Spatial Statistics using PME Metrological Data (1978-2017).

Figure 4. Variation of temperature-humidity index in different seasons. (a) Spring, (b) Summer, (c) multi - year average (1978- 2017), (d) Autumn, (e) Winter.

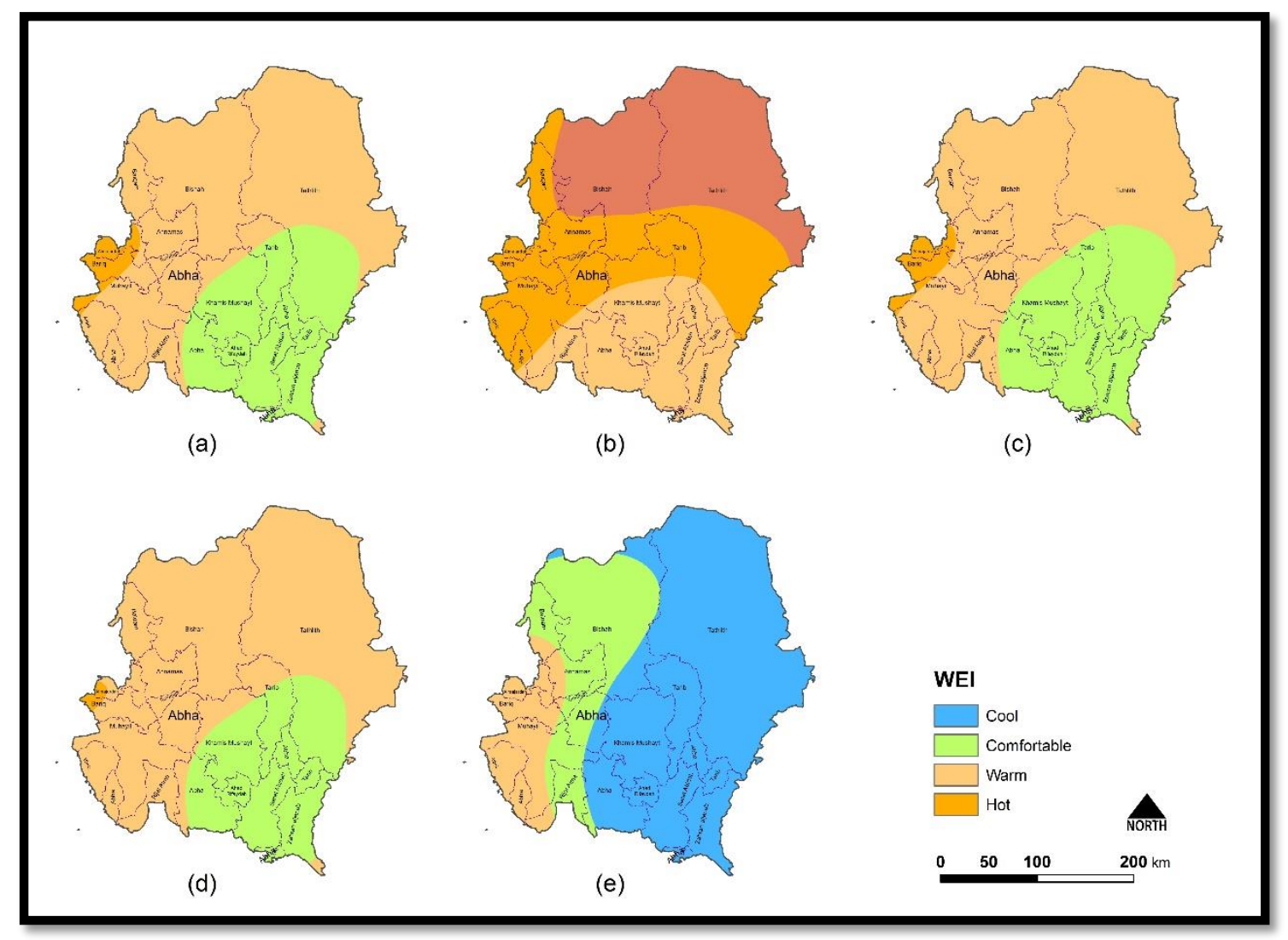

Source: Spatial Statistics using PME Metrological Data (1978-2017).

Figure 5. Variation of wind effect index in different seasons. (a) Spring, (b) Summer, (c) multi - year average (1978- 2017), (d) Autumn, (e) Winter.

\section{The Human potential of the study area}

Asir has many human resources that are still lofty today, the most important of which are:

\subsection{Archeological sites}

Ahd rafida, Hadbat aleurus, Rock inscriptions in Badia Bani Amr, Shamsan Castle, and Wadi Ayan.

\subsection{Historical sites}

Palace Shada, Ibn Hamsan Heritage Village and Almulaha Palace.

\subsection{Museums}

Muftaha Palace Museum archaeological in Abha, Shada Palace Museum in Abha, fort Tanumah popular heritage in Abha and Abdul Aziz Al - Khushn Museum in Ahad Rafidah.

\subsection{Heritage villages}


In Asir region, sites and heritage villages, were confined to about 4275 villages (General Authority for Tourism and Urban Heritage, 2019).

\subsection{Festivals and Parties Summer}

Which takes place annually and witnesses many events and sports activities of all kinds.

\subsection{Popular markets}

Asir characterized like other regions of the Kingdom with its popular markets, which is one of the oldest markets, and flocking to thousands of tourists and visitors flock to such markets. Most of these markets are called of days, such as Tuesday Market and Friday Market which are shops and the stalls are open.

\subsection{Parks and gardens}

There are number of parks and gardens in the Asir region, Shows and explain figure (6): Classification of parks by height. Table (2): Quantitative analysis of park heights.

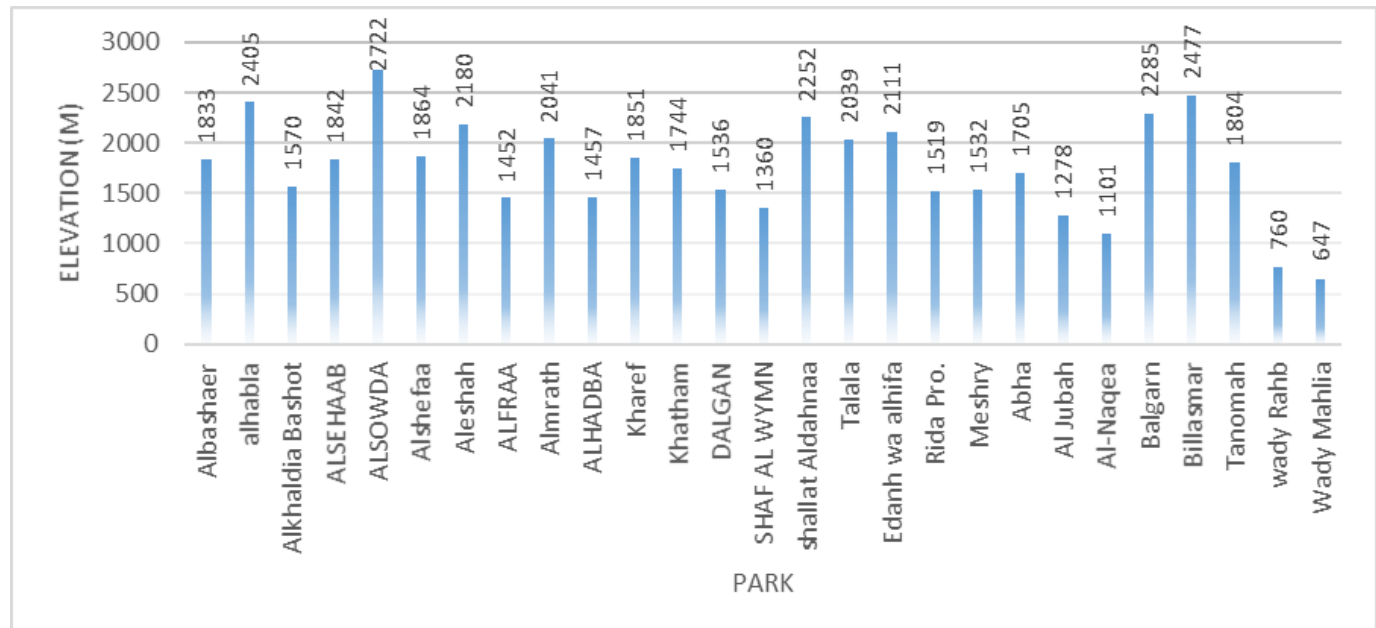

Source: Detailed Landuse plan, Asir Municipality, 2018 shuttle Radar Topography Mission (SRTM) 3 Arc-Second Global, NASA \& NGA, 2011.

Figure 6. Classification of parks and gardens by height.

Table 2. Quantitative analysis of park heights.

\begin{tabular}{cc}
\hline \multicolumn{2}{c}{ Elevation $(\mathrm{m})$} \\
\hline Mean & 1754.33 \\
\hline Standard Error & 94.83 \\
\hline Median & 1804.00 \\
\hline Standard Deviation & 492.78 \\
\hline Sample Variance & 242828.38 \\
\hline Kurtosis & 0.15 \\
\hline Skewness & -0.31 \\
\hline Range & 2075.00 \\
\hline Minimum & 647.00 \\
\hline Maximum & 2722.00 \\
\hline
\end{tabular}

Source: Detailed Landuse plan, Asir Municipality, 2018 shuttle Radar Topography Mission (SRTM) 3 Arc-Second Global, NASA \& NGA, 2011. 

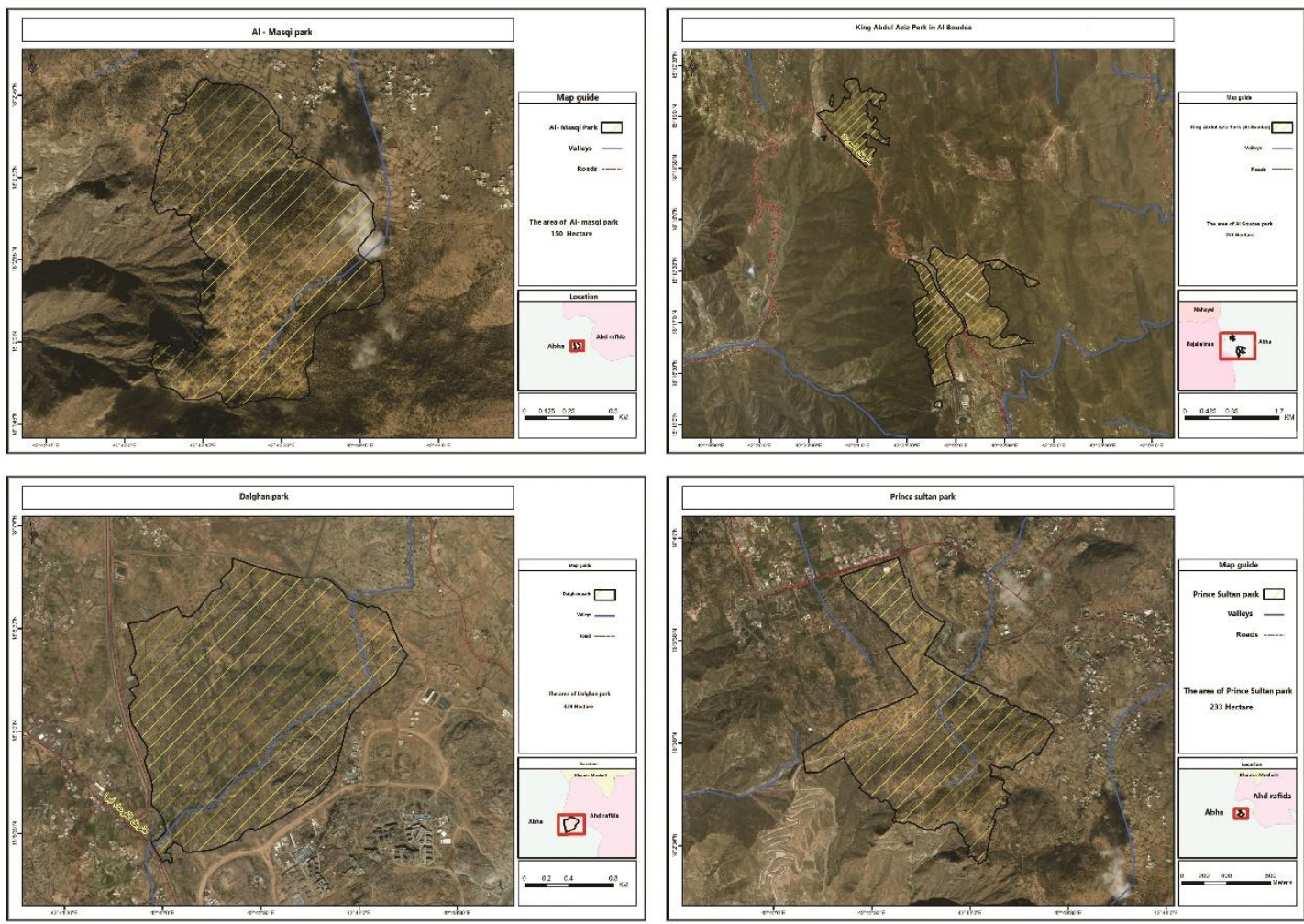

Source: Ministry of Environment, Water and Agriculture, 22/10/2019.

Figure 7. Lactation some of the parks in study area.
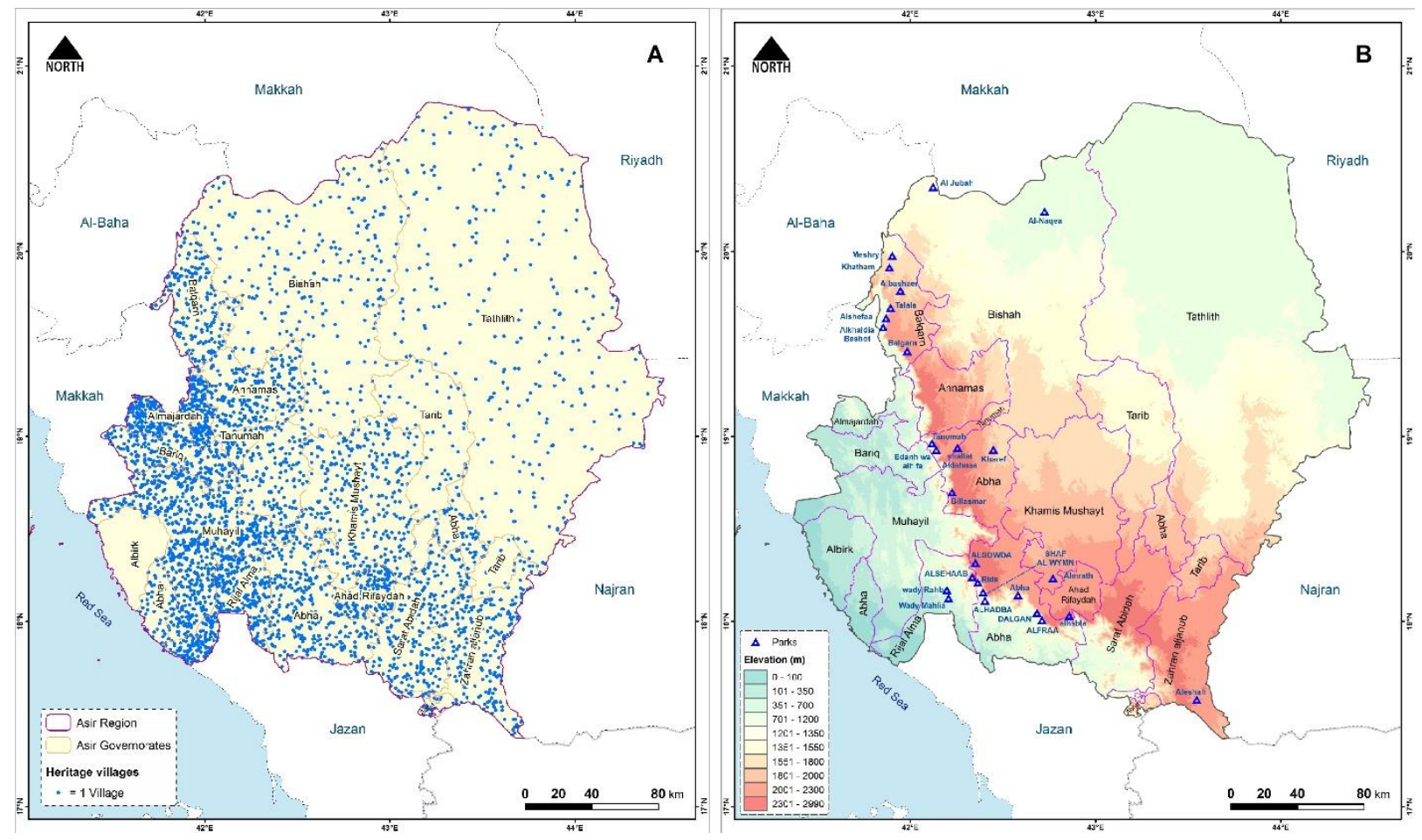

Source: Detailed Landuse plan, Asir Municipality, 2018 shuttle Radar Topography Mission (SRTM) 3 Arc-Second Global, NASA \& NGA, 2011.

Figure 8. (A) Heritage villages and, (B) parks and gardens by height in study area. 


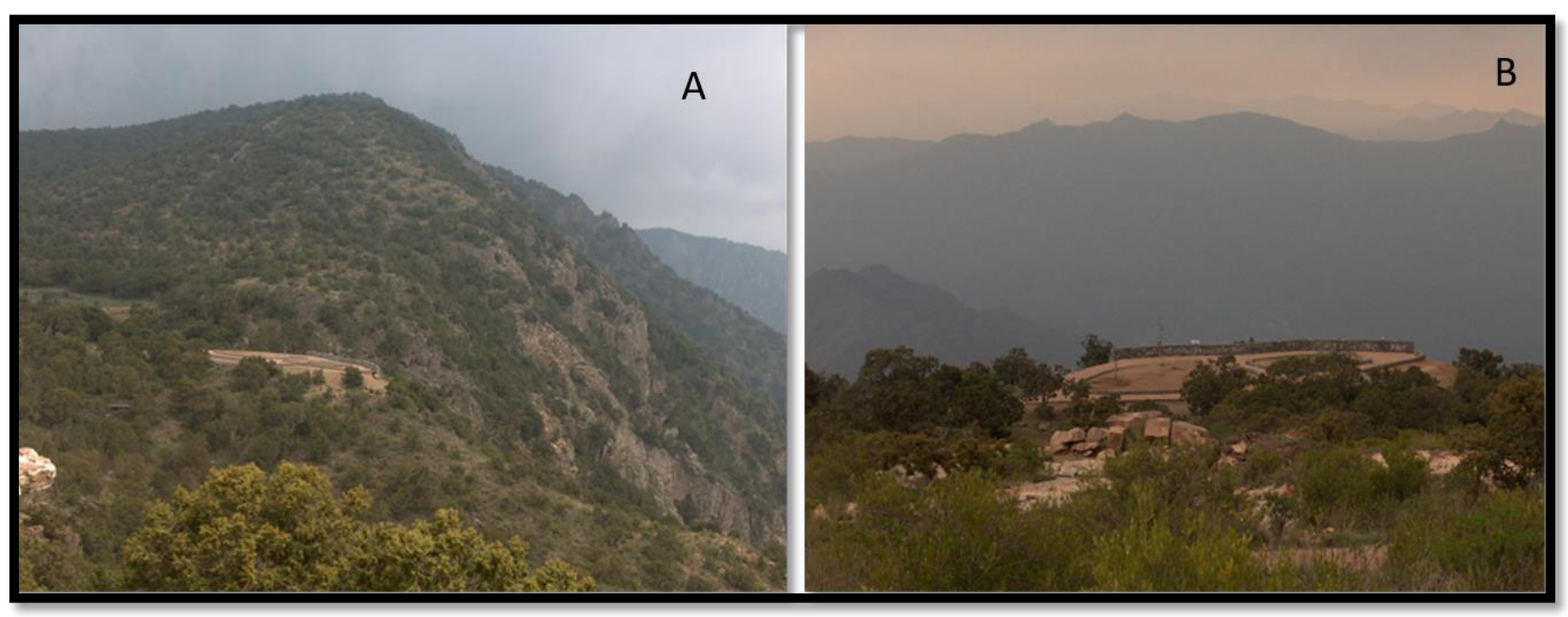

Figure 9. Field Study in the area in 15/10/2019, A and B Al-Soudah Park (King Abdulaziz).

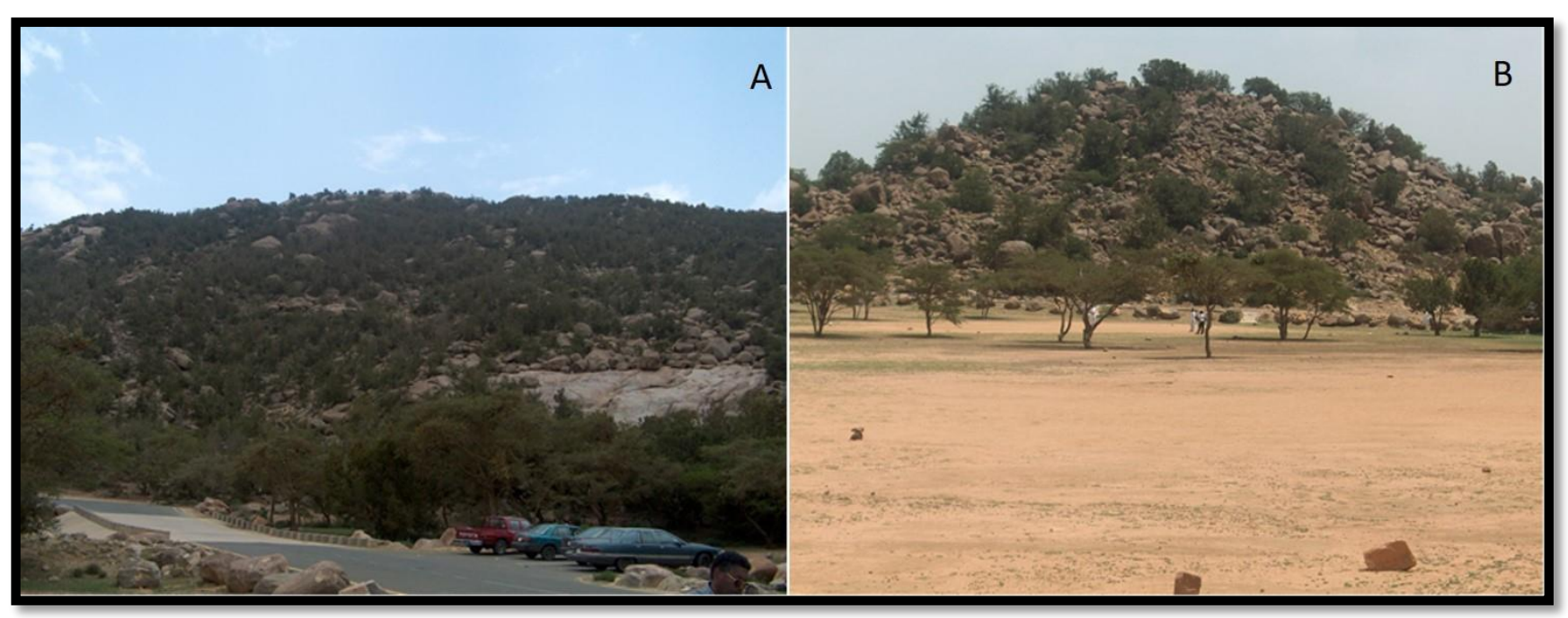

Figure 10. Field Study in the area in 15/10/2019, A and B Prince Sultan Park and Al Maskqi (Al Qara'a).

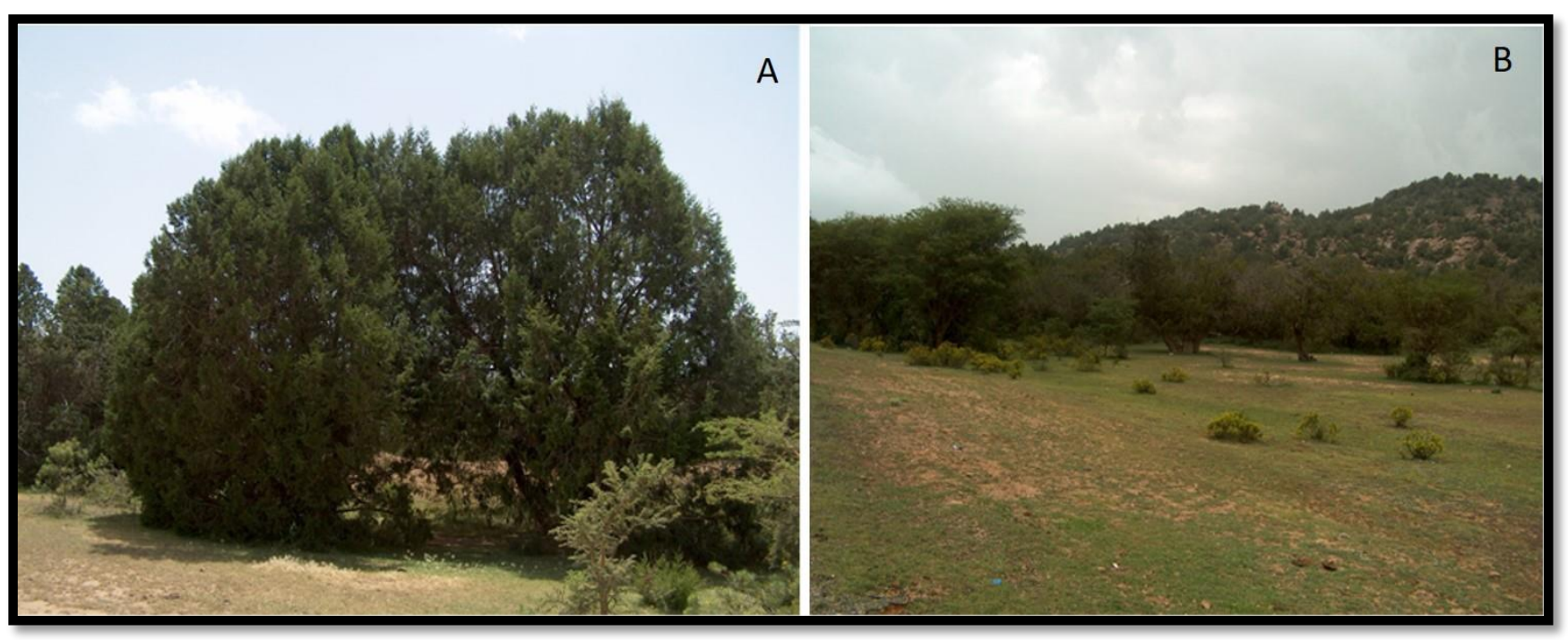

Figure 11. Field Study in the area in 15/10/2019, A and B El jar park. 


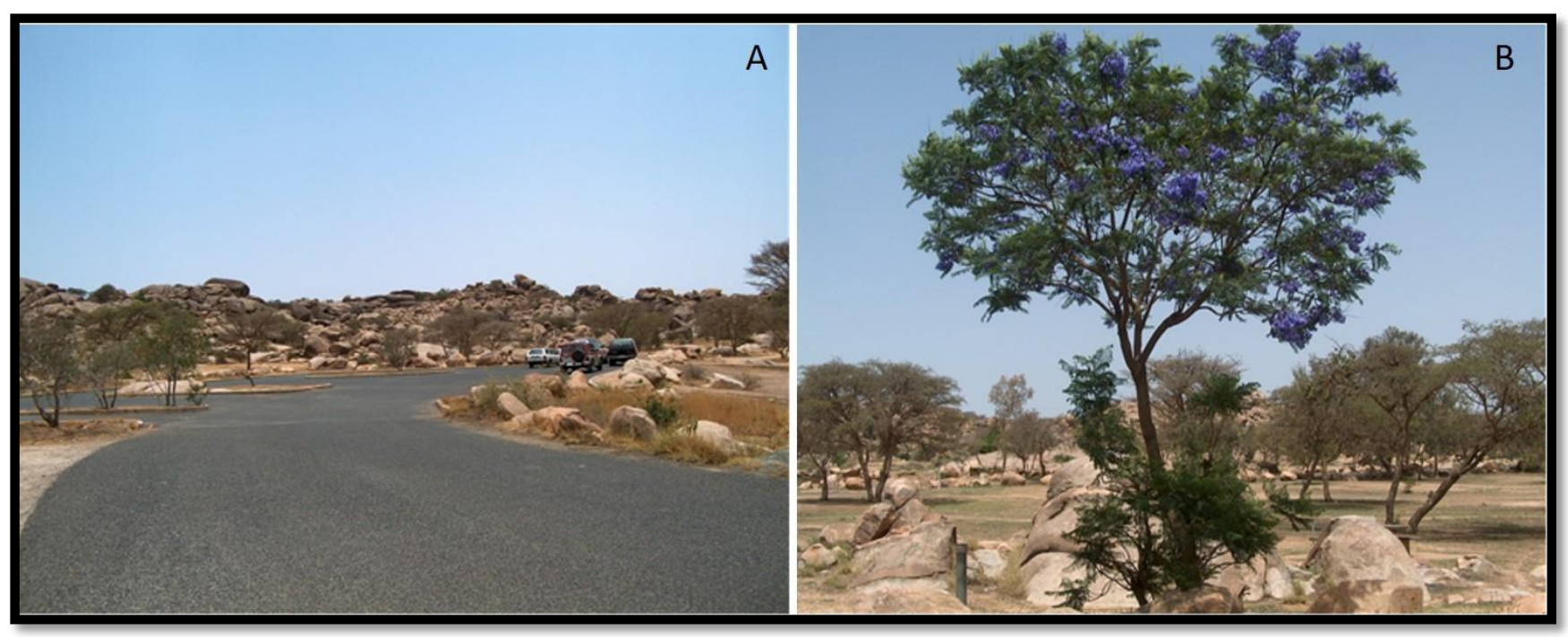

Figure 12. Field Study in the area in $15 / 10 / 2019$, A and B Dalgan Park.

\section{Evaluation of disaster risk:}

Mountains provide a thoroughly challenging environment for special sports and leisure activities which attract aficionados such as mountains paragliders, or downhill skiers (Mountain, 1995). Mountain geotourism, especially mountain adventure tourism, differs from general mass tourism in low land regions due to its higher requirements on the safety of the tourism area (Beedie, 2003). Natural hazards e.g. volcanic eruptions, seismic events, landslides, avalanches in the high mountain regions, high waves and intense precipitations, hurricanes for coastal areas etc. can affect tourist activities and tourist destinations and also can substantially modify the landscape of a certain region. The paper will present some examples of natural hayards affect geosites and tourist activities and tourist destinations in negative and pozitive way (Ilieş, 2010). 

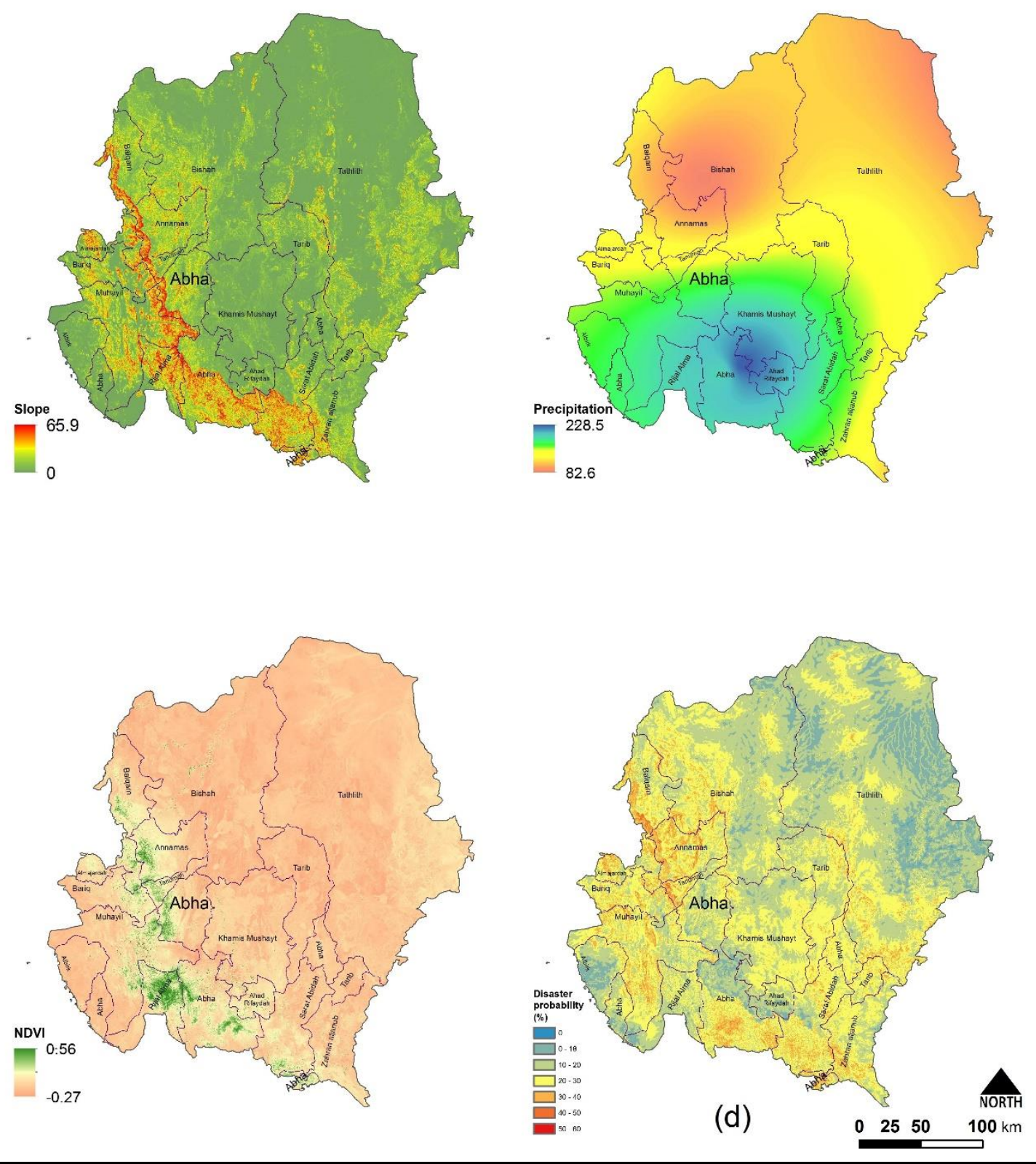

Source: Slope: shuttle Radar Topography Mission (SRTM) 3 Arc-Second Global, NASA \& NGA, 2011.- NDVI: Landsat 8, OLI, 2019, Different scenes3.- Precipitation: Spatial Statistics using PME Metrological Data (1978-2017)- Disaster Map: Spatial Statistics using ArcGIS Environment.

Figure 9. Evaluation of natural disaster risk. (a) slope, (b) precipitation, (c) NDVE, (d) results of disaster risk.

\section{Environmental Diversity Impacts on Tourism in Asir:}

Since the establishment of the General Authority for Tourism and National Heritage in 2000, Saudi Arabia has sought to facilitate the aggressive development of tourism on at the national level. The efforts so far are likely to bring about massive tourism expansion in the upcoming years. Development in the Saudi tourism sector has rather focused on areas of high potential to be mass markets, i.e. Due to their natural elements, environmental Diversity, mild climate, natural beauty, 
good infrastructure, hospitality and historic sites, regions included in the National Tourism Plan, such as Asir region, have become tourist destinations on national and international scales. Domestic tourism has soared in the recent years. More than four million domestic trips were recorded in 2010, of which nearly 430,000 involved Asir (Heritage, 2015). Domestic tourism's revenues increased by $80 \%$ between 2013 and 2014, which is an increase of 18.5 billion Saudi Riyal (US \$4.93) (ALMamony, 2015). Asir is now considered as the main tourist attraction in the Kingdom of Saudi Arabia. Hundreds of local, Arab and international tourists annually visit the region. Asir is currently one of the most popular tourist destinations in the Arab World and has been selected to be the Capital of Arab Tourism in 2017 (Arab Tourism Organization, 2015).

As tourism moved into the 21st century, the enterprises have made the environment a priority. Tourism now is the world's largest industry; therefore, the environment is taking the centre stage in tourism development (Muhanna, 2006). Tourism is not only a powerful economic force but also a factor in the physical environment. Any form of industrial development brings about an impact on the physical environment in which it takes place. In view of the fact that tourists have to visit the place of production in order to consume the output, it is inevitable that tourism activity is associated with an environmental impact. For this reason, some authors have traditionally pointed out that tourism can lead to environmental negative consequences. The highly polarized nature of development also generates intense environmental problems. This reduces the quality of life for the locals, as well as the tourists and may ultimately threaten the viability of the tourist industry itself (Williams \& Shaw, 1991). Depletion of natural resources can result in water shortages; creating a great pressure on other local resources like energy, food, etc. That might be in short supply already or destroy beautiful scenic landscapes. Pollution from tourists has an impact at the global level, which disturbs the local population of the caused community. Solid waste and littering in the nature despoil the natural environment. Physical effects can include degradation loss of wildlife habitats and of scenery and disturbance and erosion of the local ecosystem caused by clearing forested land and construction of tourism facilities and infrastructure (UNEP, 2001). However, tourism can be positive for the preservation of natural areas. In many tourism projects, the conservation of the natural, cultural and built environment is an important motivation for the initiation of the project. Moreover, some projects deter local communities from illegal use and overuse of natural resources. They also integrate protected natural areas in regional and local development plans and programs. Therefore, tourism should positively contribute to environmental preservation. This can be more meaningful when we think about tourist motivation in visiting one specific place. The benefits and costs of environmental impacts are highlighted below (Jaber \& Marzuki, 2018, p.5), table (3) show Environmental Impacts: A Comparison between benefits and costs.

Table 3. Environmental Impacts: A Comparison between benefits and costs.

\begin{tabular}{|c|c|}
\hline Benefits & Costs \\
\hline $\begin{array}{l}\text { - } \begin{array}{c}\text { Conservation of natural areas and } \\
\text { wildlife. }\end{array} \\
\text { - } \quad \text { Re-evaluation of environmental policies } \\
\text { to respond to tourism growth. } \\
\text { Increased environmental awareness and } \\
\text { respect for nature among tourists. } \\
\text { Rehabilitation and occasional } \\
\text { - } \quad \text { Introduction to planning and } \\
\text { management. } \\
\text { facilities. } \\
\text { Tourism may be less damaging to nature } \\
\text { compared with human activities involving } \\
\text { agriculture and forestry. }\end{array}$ & $\begin{array}{l}\text { Loss of aesthetic values. } \\
\text { - } \quad \text { Noise. } \\
\text { - } \quad \text { Generation of waste. } \\
\text { Cutting down trees to obtain firewood resulting } \\
\text { in water and air pollution. } \\
\text { Disturbance of ecosystems and disruption of } \\
\text { animal breeding patterns and habitats. } \\
\text { Destruction of beaches, dunes, coral reefs and } \\
\text { many national parks and wilderness areas through } \\
\text { trampling and/or use of vehicles. } \\
\text { Change of landscapes permanent } \\
\text { environmental modification. } \\
\text { Seasonal effects on populations' densities and } \\
\text { structures. }\end{array}$ \\
\hline
\end{tabular}


- $\quad$ Overuse of resources.

Source: (Muhanna, p.20, 2006).

The ability of big and small operators to utilize their supply chain to support sustainable tourism could be an important driver for change. This might require financial support for SMME's to enable them to both change their own operational practices and to understand the opportunities that they have in influencing the supply chain. The involvement of the community could also be an important marketing point (Muhanna, p.29, 2006). The impact of media focusing on the programme of tourism is already having an impact. A similar approach for environment might also result in a positive incentive.

\section{Multi-Criteria Evaluation MCE:}

It has been used this analytical method Multi-Criteria Evaluation MCE to build a model that defines tourist areas, the idea of a multi-criteria assessment method is based on the production of Suitability Maps for tourism.

\section{- Elements model Summer tourist areas in Asir region:}

The elements of the model were determined based on the most important natural ingredients and tourist attractions, give it weight depending on the degree of importance. These elements are mountain highland areas, it should be more than 900 meters above sea level for low temperature in summer with height. And vegetation to be stunning views. And with appropriate regression less than 15 degrees to establish facilities and roads, Figure (10, A) shows the best areas suitable for summer tourism, in accordance with previous standards and Criteria.

\section{- Elements model winter tourist areas in Asir region:}

Elements have been identified the model winter tourist areas according to the degree of importance in the tourist attractions for the purpose of Eco-tourism. The model included five elements are basins of valleys (to determine the distance safe), vegetation to be stunning views, topographic low (for the warmth of winter), slopes degree for the establishment of facilities and roads, and away from water flooded areas. In addition to land resources (plain areas), Figure (10, B) shows the best areas suitable for winter tourism, in accordance with previous standards and Criteria. 

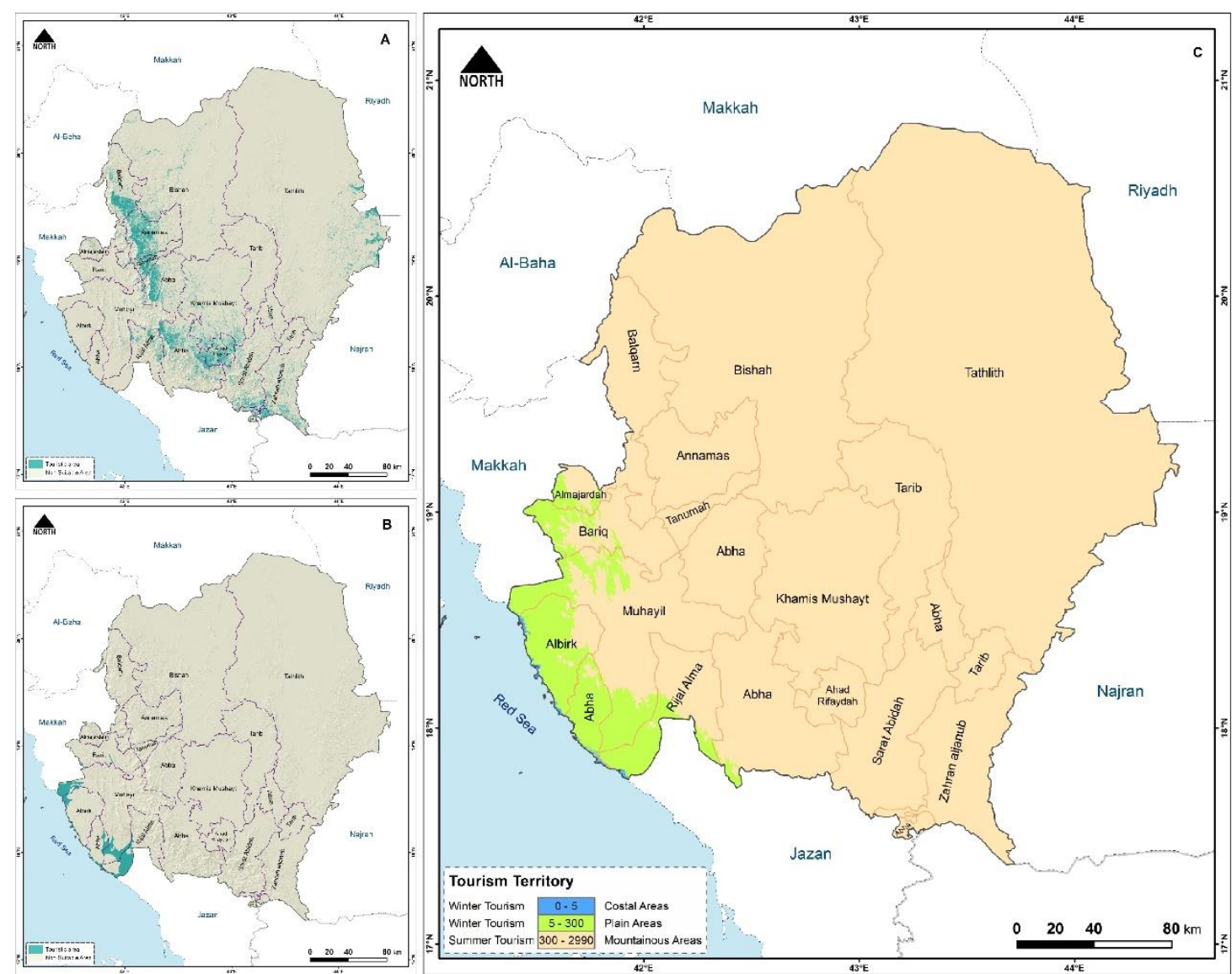

Source: Cartographic Modeling using ArcGIS Environment.

Figure 12. (A) The best areas suitable for summer tourism, (B) best areas suitable for winter tourism, tourism territory in Asir region.

Based on the case study, some general recommendations are present to address the current problems for environmental diversity assessment for geotourism development in Asir region: (1) improving the quality of manmade tourism resources and enriching cultural tourism products through cultural creativity; (2) integrating tourism industry with regional development, strengthening regional cooperation with nearby tourism areas and focusing on construction of tourism infrastructure in backward areas; (3) designing tourist sightseeing routes adapting to the spatial and temporal characteristics of different landscapes; (4) respecting the laws of nature and avoiding exploitation in areas with fragile natural ecology Sustainability and high risk of natural disasters; (5) strengthening construction of infrastructure and building up a complete tourism traffic network. We should not only focus on the quantity of geotourism resources, but also pay attention to their quality and spatial layout.

\section{Results and Discussions:}

The result of our research consists in achieving the digital map of landforms with geotouristic potential of Asir region using GIS analysis. On the map we have represented only spectacular landforms, respectively those areas where geological and geomorphological can be a resource for practicing geotourism.

The summer and winter resorts each of both in Asir are among the best resorts in the kingdom, and this region is well connected with the kingdom's other areas by air through a regional airport in Abha and by land through a network of roads that extend across the valleys and mountains. In addition to the integration of their infrastructure which contains transportation, water, electricity and modern communications, the upper structure is also integrated into gardens and parks 
together with availability of various touristic services. This in turn was reflected in higher involvement of Saudis in domestic travel trade and employment in tourism and hospitality industry. However, the impact of tourism development on the environment has not been properly assessed (Briassoulis, 2000). Overcrowding and environmental risks resulting from excessive use of natural and cultural resources resulting from tourism activities have already resulted in degradation of the natural resources on which the industry depends. The National Commission for Wildlife Conservation and Development (NCWCD) was created in 1986 to manage wildlife reserves (Seddon \& Khoja, 2003). Thus, the geological diversity along with the age of the lithologic deposits and the morphological variety individualized the Asir Mountains, with real possibilities of practicing geotourism.

\section{Conclusions:}

The paper aimed to analyze environmental diversity of Asir region for geotourism development in the region Climate and geography turn Asir into a tourist attraction all year round. In these senses were analyzed the geological and geomorphological features of our study area, were identified landforms which consists in geotouristic attractions and were represented their spatial distribution on the resulted digital maps. It is essential to analyze the status of tourism in Asir to ascertain the potential of domestic tourism for a sustainable regional development in Saudi Arabia, and tourism diversification in this region can be undertaken in terms of product, market and geographical areas. As Tourism development projects are massive undertakings. They affect many sectors and involve many stakeholders. Hence, it is critical that the government adopts multihierarchical, inclusive and well-coordinated development strategies. All-inclusive and coordinated development strategy, and these are the challenges to which the country's tourism industry should respond to promote domestic tourism.

In order to achieve sustainable tourism development in Asir, it is prudent to analyses the environmental diversity in the region. An understanding of the relationship between domestic tourism and sustainable regional development in Saudi Arabia is crucial. Preserving of environmental diversity contributes to sustainable tourism socially and economically as it operates on a platform of nature conservation and community awareness. Asir region is a unique tourist destination, it has considerable unrealized ecological potential. The government policy on domestic tourism should be reviewed. Tourism product and market diversification in the region is possible, considering that the province has many distinct geographical areas. Good tourism policies should promote resource diversity and respond to challenges facing the tourism sector in a manner that advocates sustainability. Environmental impacts on ecosystems, whenever negative effects on the natural environment are dealt with, should be consider that these impacts rarely effect on entity only. The ecological impacts of tourism usually affect the ecosystems as a whole. natural environment does not only affect pristine natural areas, but also cultivated land, which is an important part of the natural and cultural heritage of the region, it is ecologically valuable. Environmental impacts of tourism occur at the local, regional and global level. The study came out a digital Suitability Map, a comprehensive tourist area are available elements tourist attractions for Asir region in the summer and winter, and rectifiers environment unique.

On behalf of all authors, the corresponding author (Dr. Mena Elassal) states that there is no conflict of interest.

\section{Sources:}

General Authority for Tourism and Urban Heritage, 2019.

General Authority for Meteorology and Environmental Protection.

Ministry of Environment, Water and Agriculture, 22/10/2019. 


\section{References:}

Ahmad, A. (2015). Conservation of Island Biodiversity in Brunei Darussalam: The Role of Ecotourism in Environmental Education. - International Journal of Ecology \& Development 30: 51-63.

Beedie, P.\& Hudson, S. (2003). Emergence of mountain-based adventure tourism. Ann. Tour. Res. 30, pp. 625643.

Castro, EV, Souza TB, Thapa B (2015). Determinants of tourism attractiveness in the national parks of Brazil. Parks Journal 21(2): 51-62.

Chien, M. C. (2016). An Empirical study on the effect of attractiveness of ecotourism destination on experiential value and revisit intention, Applied ecology and environmental research 15(2): 43-53.

Chiu, Y.-T. H., Lee, W.-I. and Chen, T.-H. (2014). Environmentally responsible behavior in ecotourism: Antecedents and implications. Tourism Management, 40, 321-329. doi:10.1016/j.tourman.2013.06.013.

Eshtayeh. \& Jamus, M.R. (2002). Biodiversity: It's importance and methods of preservation it. Biodiversity and Environmental, 1, pp. 1-38.

Greco S, Ehrgott M, Figueira J (Eds) (2016). Multiple criteria decision analysis: State of the art surveys (2nd edn). Springer, New York. https://doi.org/10.1007/978-1-4939-3094-4.

Hou Jiang, Yaping Yang, and Yongqing Bai. (2018). Evaluation of All-for-One Tourism in Mountain Areas Using Multi-Source Data, MDPI, Sustainability, PP. 1- 19.

Jaber, H. M.; Marzuki, A. (2018), Environmental diversity in Asir region and its impact on tourism development sustainability, Academy of Entrepreneurship Journal, Volume 24, Issue 2, pp. 1- 6.

Raham athulla, M. (2018). Comparative assessment of different marketed brands of atorvastatin tablets in Asir region, Saudi Arabia, Moj Drug Design Development and Therapy, Volume 2 Issue 1, DOI: 10.15406/mojddt.2018.02.00023.

Reynard E., (2009), Geomorphosites, eds. Reynard, E., Coratza Paola, Regolini - Bissig Geraldine, Verlag Dr. Friedrich, Munchen.

Reynard E., (2008). Scientific research and tourist promotion of geomorphological heritage, Geogr. Fis. Dinam. Quat., 31, pp. $225-230$.

Reynard E., (2005a), Géomorphosites et paysages, in Géomorphologie, Relief, processus, environnement, 3 : 181-188.

Reynard E., (2005b), Geomorphological sites, public policies and property rights. Conceptualization and examples from Switzerland, in Il Quaternario 18, 1: 321-330.

Maddison, D.; Maddison, D. (2001). In search of warmer climates: The impact of climate change on flows of British tourists. Clim. Chang, 49, 193-208.

Martins, B. \& Pereira, A. (2018). Residents' Perception and Assessment of Geomorphosites of the Alvão Chaves Region, 8,381; doi:10.3390/ geosciences8100381.

Muhanna, E. (2006). Sustainable tourism development and environmental management for developing countries. Problems and Perspectives in Management, 4(2), 14-30.

Mountain, Forum. (1995). International NGO Consultation on the Mountain Agenda: Summary Report and Recommendations to the United Nations Commission on Sustainable Development; Mountain Institute: Franklin, WV, USA.

Ólafsdóttir, R. and Dowling, R. (2013). Geotourism and Geoparks - A Tool for Geoconservation and Rural Development in Vulnerable Environments: A Case Study from Iceland. Geoheritage, 6 q (1), 71-87. doi:10.1007/s12371-013-0095-3 
SAFARABADI, Azam. (2016). ASSESSING ECOTOURISM POTENTIAL FOR SUSTAINABLE DEVELOPMENT OF COASTAL TOURISM IN QESHM ISLAND, IRAN, European Journal of Geography ISSN: 1792-1341, Volume 7, Number 4:53 - 66.

Som, A.P.M.; Al-Kassem, A. H. (2013). Domestic Tourism Development in Asir Region, Saudi Arabia. J Tourism Hospit- ISSN: 2167-0269, pp. 1-4.

(C) 2020 by the authors. Submitted for possible open access publication under the terms and conditions of the Creative Commons Attribution (CC BY) license (http://creativecommons.org/licenses/by/4.0/). 